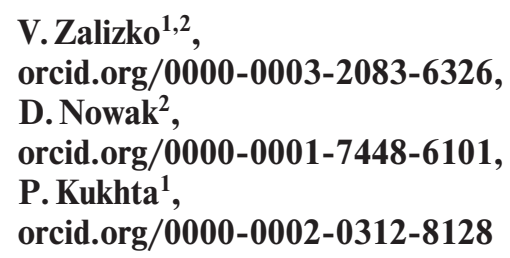

\section{ECONOMIC SECURITY OF UKRAINE: INNOVATIVE CONCEPT OF STRENGTHENING IN THE CONTEXT OF COVID-19}

1 - Taras Shevchenko National University of Kyiv, Kyiv,

Ukraine, e-mail: zwd@ukr.net

2 - Poznan University of Economics and Business, Poznan, Poland the basis of systematization and generalization of domestic and international experience in strengthening of national economic security during crisis events.

Methodology. The developed conceptual model for assessing Ukraine's economic security integrates the methodological recommendations of domestic and Polish research centers to determine the relevant integral index, which will be used as the only indicator of the national economy protection level. The scientific basis of the proposed model is the methodology of integral assessment, which determines the weight of sub-indices and indicators that will characterize the level of the integral index of the country's economic security in crisis conditions.

Findings. A theoretical approach is substantiated to the formation of an innovative concept of Ukraine's economic security strengthening in the context of COVID-19, which provides for the formation of the gig-economic space as a new key driver of the national economy in the context of global epidemiological instability. An innovative system of weighted indicators of the economic security integral index is proposed. The proposals for the use of blockchain technologies make it possible to attract domestic public investment for training, soft loans and retraining of the economically active population in the amount of 1 billion dollars.

Originality. The scientific novelty of the proposed research is to modernize the assessment system of economic security of Ukraine by introducing a new weighting system of indicators and epidemiological sub-index, the use of which will allow more accurate forecasting and increase the efficiency of the state management of economic safety of national economy in the context of the epidemic and the financial crisis.

Practical value. The proposed methodological approach forms a reliable theoretical basis for solving a number of scientific and practical problems related to the search for quick and effective management solutions caused by the new economic policy, as well as provides practical financial and economic tools to strengthen the economic security of Ukraine in the context of structural innovation and investment changes caused by COVID-19.

Keywords: innovative concept, gig-economic space, integrated index of economic security, epidemiological sub-index, COVID-19

Introduction. Today, the world economy is at another bifurcation point. Given that all socio-economic and geopolitical processes are cyclically repeated, it is worth paying attention to the well-known five-year plan for 1986-1991, which ended with the dissolution of the USSR into 15 independent states (Table 1).

A comparative analysis of the data in Table 1 indicates that in connection with the possible collapse of the Russian Federation, a number of measures should be taken to minimize the threats to economic security and sovereignty of Ukraine. The history of changes in the geopolitical situation has a pronounced cyclical trajectory, the frequency of which tends to increase over the years. Therefore, according to our calculations, the decline in oil prices and the COVID-19 pandemic will provoke inflation of the national currencies of all countries with commodity-oriented economies. The Ukrainian economy will be no exception, but unlike the Russian Federation and Venezuela, the reduction in the price of fuel and lubricants will have a positive socio-economic effect, since Ukraine is largely an importer of petroleum products and natural gas. It should be noted that during epidemics and pandemics, there is a rapid increase in prices for agricultural products, which are the main export goods of domestic producer - this opens up new opportunities for competitive advantages and super profits.

However, the Ukrainian authorities should not continue to build a system of economic protection of the country solely on the sale of agricultural raw materials, since this path will lead to tragic consequences. Therefore, for security economists, a mega-urgent problem is to improve the official methodology for assessment of the country's economic security, specified in the Methodological Recommendations for Calculating the Level of Economic Security of Ukraine [1], which unreasonably do not take into account the epidemiological indicators, which are

(C) Zalizko V., Nowak D., Kukhta P., 2020 critically important in modern conditions. Moreover, during the national quarantine caused by COVID-19, it is necessary to have an effective concept of Ukraine's economy strengthening, which will activate the shift of the national economy to a new technological paradigm, form the basis for expanding of the gig-economic space as a key driver of the national economy.

Literature review. Among national researchers who have studied the problems of strengthening economic security at the micro-and macro-levels in the context of global financial, economic and environmental crises, special mention should made of such researchers as I. Belousova, O. Kyrychenko, V. Sidak [2], Z. Varnalii, S. Onyshchenko [3], L. Karpenko, O. Zhylinska [4], V. Potapenko [5], Yu. Kharazishvili, A. Shevchenko [6], B. Storoshchuk [7], and others. In particular, [2] describes options for strengthening the economic security of various economic entities in the context of the global financial crisis, [8] provides a new methodology for assessing economic security for local territories in an unstable socio-economic and demographic situation, and [7] highlights the factors of Ukraine's economic security increasing due to the transformation of economic power in the current global crisis caused by the COVID-19 pandemic.

Among foreign scientists whose experience will be useful for strengthening the economic security of Ukraine, we shall highlight the works by such Polish scientists as: M. Popławski, T. Smal [9], M. Kośny, M. Piotrowska [10], K. Śmiałek, W. Śmiałek [11], who are actively modernizing the theory and practice of economic security of the Republic of Poland. However, these researchers did not pay attention to issues related to strengthening the economic security of the state in the context of epidemics and pandemics, in particular COVID-19.

Results. The world scientific community of the most developed countries has not paid due attention to the issues of quantitative and qualitative assessment of the economic security level, as evidenced by low publication activity. Today, scientists from 
Table 1

Fixed points that led to the changes in economic systems and disintegration of the USSR

\begin{tabular}{|c|l|l|}
\hline No & \multicolumn{1}{|c|}{ 1985-1991 years } & \multicolumn{1}{c|}{ 2019-2025 years } \\
\hline 1 & $\begin{array}{l}\text { Crisis of the Communist } \\
\text { ideology, distrust in } \\
\text { propaganda due to } \\
\text { concealment or distortion of } \\
\text { information }\end{array}$ & $\begin{array}{l}\text { Exposure of a number of fake } \\
\text { programs and channels, } \\
\text { general distrust in media of } \\
\text { the Russian Federation }\end{array}$ \\
\hline 2 & $\begin{array}{l}\text { Failed Soviet military } \\
\text { operation in Afghanistan }\end{array}$ & $\begin{array}{l}\text { Failure of military operations } \\
\text { in Donbas and Luhansk, } \\
\text { subsidized Crimea }\end{array}$ \\
\hline 3 & $\begin{array}{l}\text { Conflict with the Saudian } \\
\text { Arabia OPEC. The decrease } \\
\text { in oil prices due to the } \\
\text { increase in oil production }\end{array}$ & $\begin{array}{l}\text { Decline in oil price below } \\
\text { USD 30 a barrel, failure of the } \\
\text { agreement conclusion between } \\
\text { the OPEC and Russia, conflict } \\
\text { with Saudi Arabia }\end{array}$ \\
\hline 4 & Chernobyl disaster & COVID-19 pandemic \\
\hline 5 & Dissolution of the USSR & $\begin{array}{l}\text { Predicted collapse of the } \\
\text { Russian Federation }\end{array}$ \\
\hline
\end{tabular}

Poland and Ukraine are among the leaders in the study and formation of new directions of economic security at the macro level of the national economy. In particular, this is confirmed by the high level of publication activity and the availability of officially approved methodological recommendations for calculating of the economic security level [1]. Among the research centers of Poland and Ukraine that study the problems of economic security assessment at the level of the information society and business space, we should note the activities of the Poznan Univer-

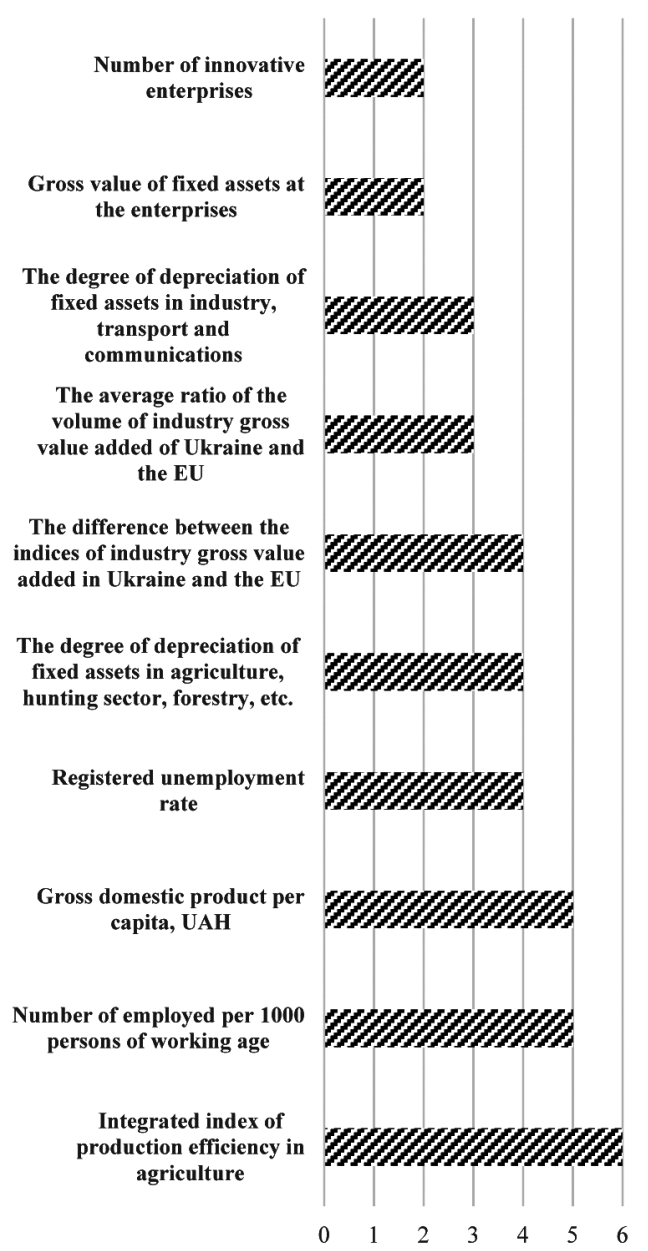

Fig. 1. Systematization of weights of economic development indicators of local territories $[9,10]$ sity of Economics and Taras Shevchenko National University of Kyiv, whose employees have generalized theoretical and methodological approaches to determine and assess the economic security of local territories of Poland [9-11], official methodological recommendations for calculating the level of economic security of Ukraine [1], as well as methodological recommendations on assessment of the economic security level of Ukraine edited by A. Sukhorukov and Yu. Kharazishvili [6], the methodology for calculating the economic security level of Ukraine, approved by the Ministry of Economy of Ukraine [12], which take into account the official indicators from [13]. Summarizing these studies, we have obtained the following diagrams of the weights of Ukraine's economic security indicators (Figs. 1, 2).

In contrast to local traditional security studies [1-6], the Polish system of economic security provision [9-11] pays considerable attention to indicators responsible for the social component (Fig. 2).

The previous study [8] proved the need to introduce a new component of Ukraine's economic security - the investmentinnovation-innovative sub-index $I$ which is proposed to be calculated by formula

$$
I=I_{1}+\frac{V_{1}+F_{1}}{V_{2}}
$$

where $I_{1}$ is an index of innovative security determined according to the World Economic Forum methodology; $V_{1}$ is cumulative investment (external and internal); $F_{1}$ is scientific and technical development costs; $V_{2}$ is gross domestic product volume.

However, under current conditions, when $90 \%$ of enterprises were forced to bring their employees into quarantine due to COVID-19 pandemic, there is an urgent need to extend the list of components of economic protection of the national economy with a block of indicators of epidemiological security (Table 2).

To determine the weights of these indicators (Figs. 1, 2 and Table 2) it is advisable to use a combination of expert estimates and stochastic methods, in particular, formulas

$$
\begin{aligned}
& \omega=M\left(X_{i}\right)-2 t \sigma\left(X_{i}\right) ; \\
& \Omega=M\left(X_{i}\right)+2 t \sigma\left(X_{i}\right) ; \\
& \lambda=M\left(X_{i}\right)-t \sigma\left(X_{i}\right) ; \\
& \Lambda=M\left(X_{i}\right)+t \sigma\left(X_{i}\right),
\end{aligned}
$$

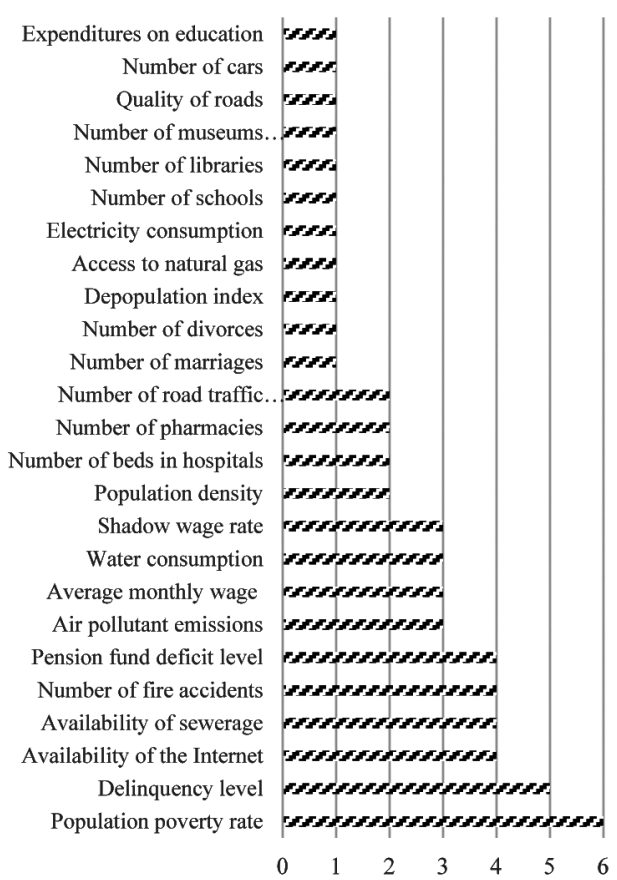

Fig. 2. Systematization of weights of social development indicators of local territories $[1,9,12]$ 
Expanded system of indicators of economic security of Ukraine and their weights [1-12]

\begin{tabular}{|c|c|c|c|c|c|}
\hline Weight & Demographic security & Weight & Energy security & Weight & Foreign economic security \\
\hline 3 & $\begin{array}{l}\text { Share of the present population in } \\
\text { the ratio of the level of } 1990\end{array}$ & 3 & $\begin{array}{l}\text { Share of the country's own } \\
\text { resources in the fuel and energy } \\
\text { resources balance }\end{array}$ & 5 & $\begin{array}{l}\text { Share of raw materials and low } \\
\text { degree of export processing }\end{array}$ \\
\hline 4 & $\begin{array}{l}\text { Dependency ratio of the } \\
\text { incapacitated population to the } \\
\text { able-bodied population (the effective } \\
\text { number of payers of insurance } \\
\text { contributions) }\end{array}$ & 4 & $\begin{array}{l}\text { Energy intensity ration of the } \\
\text { economy }\end{array}$ & 5 & Economic openness \\
\hline 2 & Life expectancy at birth & 6 & $\begin{array}{l}\text { Energy intensity ratio of the } \\
\text { shadow economy (according to } \\
\text { purchasing power parity) }\end{array}$ & 4 & Export-import coverage ratio \\
\hline 3 & $\begin{array}{l}\text { Rate of natural increase in the } \\
\text { population per } 1 \text { thousand } \\
\text { population }\end{array}$ & 4 & $\begin{array}{l}\text { Share of fuel (oil and gas) import } \\
\text { from one country or company in } \\
\text { total }\end{array}$ & 6 & $\begin{array}{l}\text { Integrated index of investment- } \\
\text { innovation-innovative security }\end{array}$ \\
\hline 5 & Depopulation coefficient & 5 & $\begin{array}{l}\text { Depreciation of fixed assets of } \\
\text { enterprises of the fuel and energy } \\
\text { complex }\end{array}$ & 6 & $\begin{array}{l}\text { Integrated index of macroeconomic } \\
\text { and financial security }\end{array}$ \\
\hline 1 & Ratio of rural and urban population & 4 & $\begin{array}{l}\text { Average level of natural gas and } \\
\text { coal reserves }\end{array}$ & 6 & Level of shadow economy \\
\hline 2 & $\begin{array}{l}\text { Ratio of long-living persons to the } \\
\text { total population }\end{array}$ & 6 & $\begin{array}{l}\text { Coefficient of rationalization of } \\
\text { the structure of energy production } \\
\text { and consumption }\end{array}$ & 5 & Current account balance \\
\hline & & 3 & Share of renewable energy sources & 4 & $\begin{array}{l}\text { GDP growth rate and its ration to the } \\
\text { average value in the EU countries }\end{array}$ \\
\hline & \multicolumn{5}{|c|}{ Food security } \\
\hline \multirow[t]{2}{*}{5} & Daily calorie intake & 5 & $\begin{array}{l}\text { Level of production and stocks of } \\
\text { grain crops at the end of the year }\end{array}$ & 6 & $\begin{array}{l}\text { Integral index of the ratio of } \\
\text { production and consumption of } \\
\text { basic food products }\end{array}$ \\
\hline & \multicolumn{5}{|c|}{ Ecological security } \\
\hline \multirow[t]{2}{*}{6} & Geo security & 6 & Aqua security & 6 & Air security \\
\hline & \multicolumn{5}{|c|}{ Epidemiological security } \\
\hline 5 & COVID-19 & 4 & $\begin{array}{l}\text { Human coronavirus (HCV-229E, } \\
\text { HCV-OC43) }\end{array}$ & 4 & Feline enteritis coronavirus (FECV) \\
\hline 5 & $\begin{array}{l}\text { Porcine respiratory coronavirus } \\
(\mathrm{PRCV})\end{array}$ & 3 & Rabbit coronavirus ( $\mathrm{RbCV})$ & 4 & Canine Coronavirus (CCV) \\
\hline 4 & Bovine coronavirus (BCV) & 4 & SARS (COV-1, 2) & 5 & MERS \\
\hline 6 & Tuberculosis & 6 & AIDS & 5 & Hepatitis, measles, etc. \\
\hline
\end{tabular}

where $\omega, \Omega, \lambda, \Lambda$ are the lower and upper threshold and optimal values of indicators, $M\left(X_{i}\right) ; \sigma\left(X_{i}\right)$ is a mathematical expectation and the mean square deviation, and $t$ is Student's constant (for more information [8]).

Epidemiological security, which is proposed to be determined by taking into account the indicators from Table 2, which will form the corresponding integral sub-index, was not taken into account in all the above-mentioned methods for assessing the level of economic security of the national economy.

A systematic analysis of the consequences of COVID-2019 epidemic caused by SARS-CoV-2 coronavirus confirms the high level of its impact on the economic security of Ukraine. This is indicated by the systematic actions of the EU, China and the USA, which are urgently forming packages of anti-crisis measures for which hundreds of billions of dollars will be allocated to strengthen the economic security of their own economies. There are currently no opportunities to create the financial security cushion in Ukraine necessary to strengthen the economic security of the national economy (primarily small and medium business) under the conditions of COVID-19.

On the one hand, as of 29.02.2020, we have total debt obligations of the state (central government, regional and local authorities, as well as the debts of all state participation corporations), which exceed UAH 2 trillion, and on the other hand military operations in the East of the country, for which about UAH 100 billion shall be provided. In such extreme financial, political and epidemiological conditions, when, as of 18.03.2020, the total tax and customs fees have decreased by almost UAH 70 billion [13] and there are not enough financial resources to support the real sector of the economy, the proper fulfillment of social obligations is under the threat. This situation prompts the Government of the country to address three issues: 1) to overcome the epidemic; 2) to save the country's population; 3) to support the real sector of the economy. The solution to this triad is impossible without realizing the country's internal potential and attracting investors (since investment funds and private investors become active during the financial crisis, buying up shares of enterprises).

If not taking into account the possibility of the IMF repeat lending, which will only partially solve the socio-economic problems and further weaken the level of economic security of Ukraine, the only way to strengthen the national economy is the shift to a new technological paradigm and formation of a full-fledged information society. To do this, we offer the following author's concept of strengthening the country's economic security.

Given COVID-19 epidemic, the proposed visualization of the innovative concept of strengthening the economic security of Ukraine (Fig. 3) shall first be implemented in the direction of formation of the institutional and financial foundation necessary to activate the gig-economic space. The term "gig" means rapidly changing nature of economic self-employment, so the notion of "gig-economic space" is a financial and economic system of free market, which provides for the exchange 
of labor force and money between organizations, natural persons-entrepreneurs, farmers, private agricultural enterprises and independent workers (freelancers) using digital platforms to participate in short-term employment agreements.

The main advantage of the gig-economic model is that citizens can individually create their economic activity. At the same time, companies get motivated employees who work under the flexible and convenient schedule. The advantages of the gig economy are positively assessed in the United States, where as of January 1, 2020, $36 \%$ of the country use the gig economy as an additional source of income (totally, 56 million gig workers are freelancers, consultants, Uber drivers, guides, volunteers, etc. generate about 1 trillion dollars in the United States, more information about the peculiarities of the establishment of gig business in [14]).

Therefore, in order for Ukraine to overcome the socioeconomic crisis caused by national and international quarantine (when all developed countries have closed their borders), it is advisable to develop affordable educational programs for different ages that show the advantages of self-employment and gig-economic space. First of all, the programs should take into account the interests and opportunities of the new generation of digitalized Alpha children and adolescents. In this regard, we should, for example, take as a model the experience of the International Innovation School, which has developed business literacy skills training programs and MBA basics starting from the 1st grade [15]. It is obvious that the success of the gigeconomic direction requires financial support, which is proposed to be attracted by simplification, digitalization and shift of $80 \%$ of administrative and government activities to blockchain technology (Blockchain), which has proven itself positively in Estonia, Latvia, Poland, the UAE and other countries. In the context of default it is necessary to reduce expenses for service of all Apparatus by $80 \%$ (according to the Pareto principle): the Verkhovna Rada of Ukraine (UAH 2.0 billion), Office of the President of Ukraine (UAH 0.9 billion), the Cabinet of Ministers of Ukraine (UAH 1.0 billion), the Ministry of Finance UAH 20 billion), the Ministry of Justice (UAH 14.0 billion), the Ministry of Culture, Youth and Sports of Ukraine

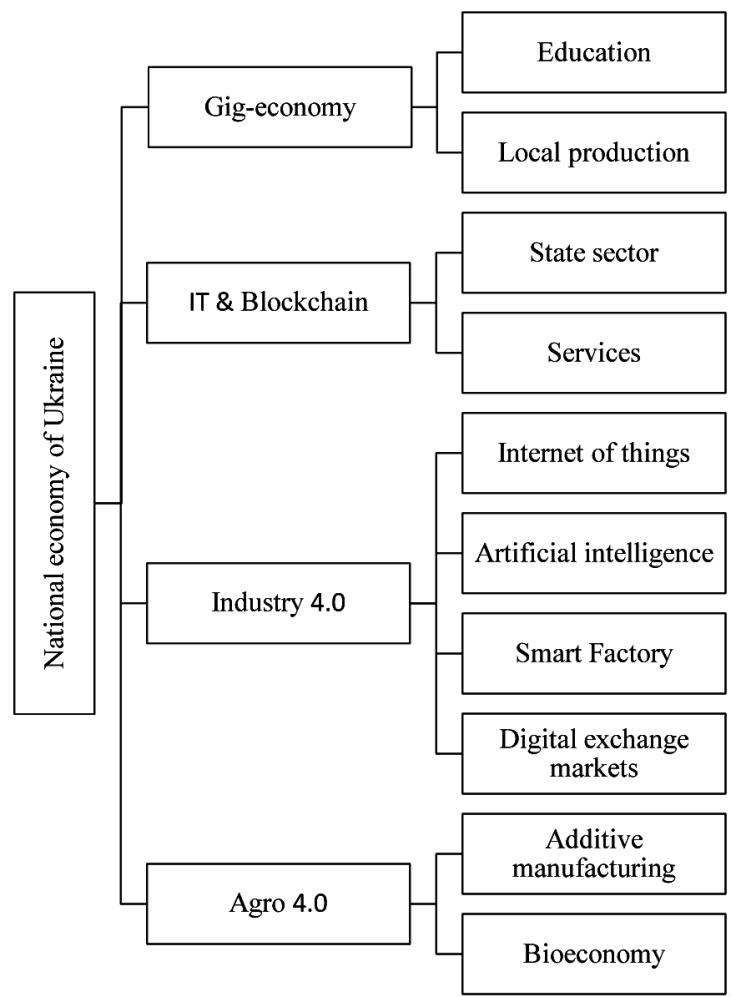

Fig. 3. Innovative concept of strengthening the economic security of Ukraine under the conditions of COVID-19
(UAH 15.4 billion), the Ministry of Information Policy (UAH 1.8 billion) and the State Management of Affairs (UAH 2.4 billion) [16], delegating some of their functions to other ministries and departments, in particular to research and classical Universities [17]. Thus, it is possible to create a state program for the development of the gig economy (in which civil servants dismissed as a result of optimization will be able to participate) for 5 years with guaranteed financial security for training and lending in the amount of UAH 230 billion. The practical possibility of shift of the state administration on the basis of blockchain is indicated by the successfully implemented strategy Dubai Blockchain Strategy 2020, thanks to which Dubai has become the world capital of blockchain in 4 years and has received the award as the first smart blockchain city [18].

The proposed innovative concept of strengthening the economic security of Ukraine provides for the digitalization of the domestic industrial sector. In particular, having analyzed the activities of the most innovative mining enterprises in Ukraine (Table 3), it should be noted that only Ukrainian Mining and Metallurgical Company PJSC and Mining and Chemical Enterprise Polimineral in Stebnyk showed the appropriate level of activity on the PFTS national stock exchanges, Perspektyva and Ukrainian exchanges.

Despite the fact that Ukraine is one of the world's leading countries in the export of titanium ores, occupying about $5 \%$ of the world market [19], national companies do not make sufficient use of investment opportunities through national and international stock exchanges. In the context of Industry 4.0 development, it is important to enter international markets by implementing horizontal and vertical integration of information and management ERP (Enterprise Resource Planning) and CRM (Customer Relationship Management) systems.

In addition to the negative effects of the coronavirus epidemic, the national economy has a chance to gain new competitive advantages, as in the short term there is a significant increase in prices for agricultural products, which is one of the main components of exports. However, Ukraine's agriculture should shift to precision agriculture, 3D modeling and forecasting of economic and environmental effects, use of agrodrons at the level of SMEs, OGC-services, GPS-navigation, biotechnologies and Big Data, which will increase yields and stimulate to sustainable development.

Considering that the leading countries allocate additional USD 4 trillion (the USA - 2 trillion dollars, the IMF - USD 1 trillion, the EU, China and Japan - USD 1 trillion) to strengthen the economic security of the national economy and stabilize financial exchanges in the context of the spread of acute respiratory disease COVID-19 caused by coronavirus SARS$\mathrm{CoV}-2$, the other countries will be forced to follow a similar path. Such an additional issue to the world economic system in the amount of 4-6 trillion dollars will lead to the devaluation of all currencies. The cyclical intensification of coronavirus infections indicates that it is necessary to shift to a new business platform of the digital economy, which does not need offices, clerks, managers, salespeople, taxi drivers, cashiers, accountants and others. In its turn, this will lead to the transformation of the service sector, which in modern conditions will increasingly use the tools of the gig economy (App-Base, Flexibility, Global, Remote, Job sourcing, In-house recruiting staff).

Conclusions. The proposed approach to the formation of an innovative concept of strengthening Ukraine's economic security is only one element of the authors' vision of the innovative conceptual sphere of digital society formation, which reveals new forms of economic solidarity and business partnership on the principles of subsidiarity. The outlined concept of strengthening the economic security of Ukraine in the context of the spread of acute respiratory disease COVID-19 caused by coronavirus SARS-CoV-2, provides for the institutionalization of gig-workers (freelancers), who must have not only tax benefits but also proper social, transport and information infrastructure. First of all, we are talking about the possi- 
Table 3

Systematization of innovative mining enterprises that have an impact on the economic security of Ukraine $[1,16,19]$

\begin{tabular}{|l|l|}
\hline $\begin{array}{l}\text { Mining and Chemical Enterprise } \\
\text { Polimineral in Stebnyk }\end{array}$ & \multicolumn{1}{|c|}{$\begin{array}{c}\text { Ukrainian Mining and } \\
\text { Metallurgical Company PJSC }\end{array}$} \\
\hline $\begin{array}{l}\text { Marhanets Mining and } \\
\text { Processing Plant PJSC }\end{array}$ & $\begin{array}{l}\text { United Mining and Chemical } \\
\text { Company PJSC }\end{array}$ \\
\hline $\begin{array}{l}\text { SE Eastern Mining and } \\
\text { Processing Plant }\end{array}$ & Mykolaiv alumina plant LLC \\
\hline $\begin{array}{l}\text { Bohuslav Quarry, Open } \\
\text { Joint-Stock Company }\end{array}$ & $\begin{array}{l}\text { Druzhkivske Rudoupravlinnya } \\
\text { PJSC }\end{array}$ \\
\hline $\begin{array}{l}\text { PJSC Kondrashivskyi Sand } \\
\text { Quarry }\end{array}$ & $\begin{array}{l}\text { Kremenchug Quarry } \\
\text { Management Quartz PJSC }\end{array}$ \\
\hline $\begin{array}{l}\text { Northern Mining and } \\
\text { Processing Plant PJSC }\end{array}$ & $\begin{array}{l}\text { Central Mining and Processing } \\
\text { Plant PJSC }\end{array}$ \\
\hline Sukha Balka PJSC & $\begin{array}{l}\text { Korostyshiv Granite Quarry } \\
\text { OJSC }\end{array}$ \\
\hline $\begin{array}{l}\text { SE Irshansk Mining and } \\
\text { Processing Plant }\end{array}$ & $\begin{array}{l}\text { Yantsevsky Granite Quarry } \\
\text { OJSC }\end{array}$ \\
\hline Glukhiv Quartzite Quarry LLC & PROMBUD LLC \\
\hline UKRPROMMAGNET LLC & Cornerstone Group, LLC \\
\hline Energy Service Company \\
Esko-Pivnich LLC & $\begin{array}{l}\text { Plant of rubber technical } \\
\text { products" AQUITENS LLC }\end{array}$ \\
\hline Granstein LLC & Rokytne Granite Quarry LLC \\
\hline Turshcheb LLC & Mining Company Mineral LLC \\
\hline $\begin{array}{l}\text { Novoselovsky Mining and } \\
\text { Processing Plant PJSC }\end{array}$ & $\begin{array}{l}\text { Shepetivka granite quarry } \\
\text { Pronex PJSC }\end{array}$ \\
\hline
\end{tabular}

bility of access to high-speed Internet in rural areas, as 12 million rural people do not have adequate access to the global gig-economic space and information environment of knowledge. In particular, during the quarantine in March-April 2020, rural children did not have free access to distance learning, due to lack of access to the Internet, which is recognized by the UN as a violation of fundamental human rights. In addition, the economically active rural population, which has returned from labor migration, will not be able to realize themselves properly without high speed Internet access.

Based on a systematic analysis of the economic situation in Ukraine, it is established that the avoidance of default in the medium and long term is possible by opening a gig-economic space, which provides for the exchange of labor force and money between organizations and independent workers (freelancers) through digital platforms. It is proposed to shift $80 \%$ of administrative and governmental activities to blockchain technology to form the appropriate financial support, which has proven itself in developed countries. The proposed optimization of the state apparatus allows attracting about 5-6 billion dollars in 5-6 years of own funds for training, soft loans rate and retraining of economically active population in 5-6 years, which complements the Program of the Cabinet of Ministers of Ukraine, in particular, in the context of business development, job creation, equal opportunities for all entrepreneurs.

The study emphasizes the theoretical part of the conceptual sphere of strengthening economic security in the digital society, which aims to improve the material well-being and well-being of economically active population by development of a gig-economic system. In the developed conceptual model of strengthening economic security of Ukraine in the conditions of COVID-19 the key emphasis is placed on importance of determination of integral index of economic security on the basis of methodology of integrated assessment of system of sub-indeces which is supplemented by epidemiological subindex the use of which enables effective state management of the system of economic security of the national economy on the basis of blockchain technology.

In the following studies, a quantitative analysis of the dynamics of the level of economic security of Ukraine and probable scenarios of development, depending on the epidemiological and international situation will be conducted.

Acknowledgments. This study was obtained in the framework of the international Polish-Ukrainian project "Central European Network for Sustainable and Innovative Economy" (No. PPI/APM/2019/1/00047/U/00001/IIC), as well as R\&D "Innovative mechanisms to enhance the development of scientific and technological activities in Ukraine" (No. 19 BF 040-02).

\section{References.}

1. Ministry for Development of Economy and Trade of Ukraine (n.d.). Order on approval of Methodical Recommendations for Calculating the Level of Economic Security of Ukraine dated October 29, 2013 No. 1277. Retrieved from http://me. gov.ua/control/uk/publish/category/main? Cat_id=38738. 2. Kyrychenko, O.A., Belousova, I.A., \& Sidak, V. S. (2010). Economic Security of Business Entities in the Context of Global Financial Crisis: monograph. Kyiv: Dorado-druk.

3. Varnalii, Z., \& Onyshchenko, S. (2019). Ukraine Budget Security: Foundations and Directions of Provision in Terms of Digital Economy Development. Economic Security at Risks: Findings from the Digitalization of National Economy: monograph. University of Economy in Bydgoszcz. Poland Publishing House, (pp. 214-236).

4. Karpenko, L., Zhylinska, O., Zalizko, V., Kukhta, P., \& Vikulova, A. (2019). Human Development in the Context of Provision of the Social Safety of Society. Journal of security and sustainability issues, 8(4), 1275-1286.

5. Potapenko, V. G., \& Biriukov, D. S. (2013). Environmental Component in the System of Economic Security Indicators. Efektyvna ekonomika. Retrieved from http: //www.economy. nayka.com.ua/?op $=1 \& z=2088$.

6. Kharazishvili, Y., \& Shevchenko, A. (2018). Strategic Planning for Sustainable Development from the Standpoint of Economic Security on the Example of the Railway Transport of Ukraine. Research Papers in Economics and Finance. Poznań University of Economics and Business, 2(4), 7-17.

7. Storoshchuk, B. D. (2020). Regularities of Transformation of Economic Power in the Conditions of the Global Crisis. Economic Bulletin of the National Mining University, 1(69), 9-22.

8. Zalizko, V. D., \& Martynenkov, V. I. (2016). Method of estimation of the Economic Security of Ukraine's Rural Territories. Economy of Ukraine, 1(650), 19-34.

9. Popławski, M., \& Smal, T. (2017). Zeszyty Podstawy Metodologiczne Badań nad Bezpieczeństwem Ekonomicznym Dolnego Śląska. Naukowe ASzWoj, 2(107), 41-58.

10. Kośny, M. (2013). Piotrowska, M. Economic Security of Households and their Savings and Credits. Warsaw : National Bank of Poland. Education and Publishing Department. Retrieved from http://www.nbp.pl/publikacje/materialy_i_studia/146 en.pdf.

11. Śmiałek, K., \& Śmiałek, W. (2019). Bezpieczeństwo ekonomiczne: wymiar narodowy i międzynarodowy. Warszawa : Centralny Ośrodek Analizy Skażeń. ISBN: 978-83-939703-2-2.

12. Ministry for Development of Economy, Trade and Agriculture of Ukraine (n.d.). Methodology for Calculating the Level of Economic Security of Ukraine, approved by the order of the Ministry of Economy of Ukraine No. 60 dated March 2, 2007. Retrieved from http://me.gov.ua.

13. MinFin (n.d.). Inflation Index in Ukraine. Retrieved from https://index.minfin.com.ua/economy/index/inflation.

14. Perera, K., Ohrvik-Stott, J., \& Miller, C. (2020). Better Work in the Gig Economy. Enabling Gig Workers to Live with Financial Security, Dignity and Dream. London.

15. Competitive Advantages of International Innovative School (n.d.). Retrieved from https://iis.org.ua. 
16. Search datasets by groups (n.d.). Retrieved from https:// data.gov.ua.

17. Zhylinska, O., Sitnicki, M., \& Vikulova, A. (2019). Systematic Assessment of Innovative Potential of a Research University. Baltic Journal of Economic Studies, 5(2), 38-44.

18. Dubai Blockchain Strategy 2020 Achievements Report (2020). Retrieved from https://www.smartdubai.ae/knowledge-hub/publications/dubai-blockchain-strategy2020-achievements-report.

19. Science Explorer. National Minerals Information Center (n.d.). Retrieved from https://www.usgs.gov/science/scienceexplorer/Minerals.

\section{Економічна безпека України: інноваційний концепт зміцнення в умовах COVID-19}

\section{В. Д. Залізко ${ }^{1,2}$, Д. В. Новак ${ }^{2}$, П. В. Кухта ${ }^{1}$}

1 - Київський національний університет імені Тараса Шевченка, м. Київ, Україна, e-mail: zwd@ukr.net

2 - Познанський економічний університет, м. Познань, Польща

Мета. Формування інноваційного концепту зміцнення економічної безпеки України в умовах COVID-19 на основі систематизації та узагальнення вітчизняного й міжнародного досвіду зміцнення національної економічної безпеки під час кризових явищ.

Методика. Розроблена концептуальна модель оцінки економічної безпеки України інтегрує в собі методичні рекомендації вітчизняних і польських наукових центрів щодо визначення відповідного інтегрального індексу, що використовуватиметься як єдиний індикатор рівня захисту національної економіки. Науковим фундаментом запропонованої моделі слугує методологія інтегрального оцінювання визначення ваги субіндексів і показників, що будуть характеризувати рівень інтегрального індексу економічної безпеки країни у кризових умовах.

Результати. Обгрунтовано теоретичний підхід до формування інноваційного концепту зміцнення економічної безпеки України в умовах COVID-19, що передбачає формування гіг-економічного простору як нового ключового драйвера національної економіки в умовах глобальної епідеміологічної нестабільності. Запропонована інноваційна система зважених індикаторів інтегрального індексу економічної безпеки. Наведені пропозиції щодо використання блокчейн технологій уможливлюють залучення внутрішніх державних інвестицій для навчання, пільгового кредитування й перекваліфікації економічно активного населення в розмірі 1 млрд дол.

Наукова новизна. Наукова новизна запропонованого у роботі дослідження полягає в модернізації системи оцінювання економічної безпеки України шляхом уведення нової системи ваг показників і епідеміологічного субіндексу, використання якого уможливить більш точне прогнозування й підвищить ефективність державного управління системою економічної безпеки національного господарства в умовах епідемії та фінансової кризи.

Практична значимість. Запропонований методичний підхід формує надійний теоретичний базис для вирішення ряду науково-практичних проблем, пов'язаних із пошуком швидкого та ефективного управлінського рішення, викликаного новою економічною політикою, а також забезпечує практичним фінансово-економічним інструментарієм для зміцнення економічної безпеки України в умовах структурних інноваційно-інвестиційних змін, спричиненими COVID-19.

Ключові слова: інноваційний концепт, гіг-економічний простір, інтегральний індекс економічної безпеки, епідеміологічний субіндекс, COVID-19

\section{Экономическая безопасность Украины: инновационный концепт укрепления в условиях COVID-19}

\author{
В. Д. Зализко ${ }^{1,2}$, Д. В. Новак ${ }^{2}$, П. В. Кухта ${ }^{1}$
}

1 - Киевский национальный университет имени Тараса Шевченко, г. Киев, Украина, e-mail: zwd@ukr.net 2 - Познанский экономический университет, г. Познань, Польша

Цель. Формирование инновационного концепта укрепления экономической безопасности Украины в условиях COVID-19 на основе систематизации и обобщения отечественного и международного опыта укрепления национальной экономической безопасности во время кризисных явлений.

Методика. Разработанная концептуальная модель оценки экономической безопасности Украины интегрирует в себе методические рекомендации отечественных и польских научных центров по определению соответствующего интегрального индекса, который будет использоваться как единственный индикатор уровня защиты национальной экономики. Научным фундаментом предложенной модели служит методология интегральной оценки определения веса субиндексов и показателей, которые будут характеризовать уровень интегрального индекса экономической безопасности страны в кризисных условиях.

Результаты. Обоснован теоретический подход к формированию инновационного концепта укрепления экономической безопасности Украины в условиях COVID-19, который предусматривает формирование гиг-экономического пространства как нового ключевого драйвера национальной экономики в условиях глобальной эпидемиологической нестабильности. Предложена инновационная система взвешенных индикаторов интегрального индекса экономической безопасности. Приведенные предложения по использованию блокчейн технологий способствуют привлечению внутренних государственных инвестиций для обучения, льготного кредитования и переквалификации экономически активного населения в размере 1 млрд долл.

Научная новизна. Научная новизна предложенного в работе исследования заключается в модернизации системы оценивания экономической безопасности Украины путем введения новой системы весов показателей и эпидемиологического субиндекса, использование которой позволит проводить более точное прогнозирование и повысит эффективность государственного управления системой экономической безопасности национального хозяйства в условиях эпидемии и финансового кризиса.

Практическая значимость. Предложенный методический подход формирует надежный теоретический базис для решения ряда научно-практических проблем, связанных с поиском быстрого и эффективного управленческого решения, вызванного новой экономической политикой, а также обеспечивает практическим финансовоэкономическим инструментарием для укрепления экономической безопасности Украины в условиях структурных инновационно-инвестиционных изменений, вызванными COVID-19.

Ключевые слова: инновационный концепт, гигэкономическое пространство, интегральный индекс экономической безопасности, эпидемиологический субиндекс, COVID-19

Recommended for publication by N.V.Vdovenko, Doctor of Economic Sciences. The manuscript was submitted 19.12.19. 